\title{
Study of the $\mathrm{Cu}, \mathrm{Mn}, \mathrm{Pb}$ and $\mathrm{Zn}$ dynamics in soil, plants and bee pollen from the region of Teresina (PI), Brazil
}

\author{
ALINE S. SILVA ${ }^{1}$, SEBASTĨ̃O B. ARAÚJO ${ }^{1}$, DARCET C. SOUZA ${ }^{2}$ \\ and FÁBIO A. SANTOS E SILVA ${ }^{2}$ \\ ${ }^{1}$ Departamento de Química, Centro de Ciências da Natureza, Universidade Federal do Piauí, \\ Avenida Universitária, s/n, 64049-550 Teresina, PI, Brasil \\ ${ }^{2}$ Departamento de Zootecnia, Centro de Ciências Agrárias, Universidade Federal do Piauí, \\ Avenida Universitária, s/n, 64049-550 Teresina, PI, Brasil
}

Manuscript received on February 18, 2011; accepted for publication on February 27, 2012

\begin{abstract}
The purpose of this study is to characterize native bee plants regarding their capacity to extract and accumulate trace elements from the soil and its consequences to the sanity of the produced pollen. The trace elements $\mathrm{Cu}, \mathrm{Mn}, \mathrm{Pb}$ and $\mathrm{Zn}$ were analyzed in soil, plants and bee pollen from Teresina region (PI), Brazil, by flame atomic absorption spectrophotometer. Considering the studied plant species, $\mathrm{Cu}$ and $\mathrm{Pb}$ metals presented in the highest levels in the roots of $B$. platypetala with 47.35 and $32.71 \mu \mathrm{g} \cdot \mathrm{mL}^{-1}$ and H. suaveolens with 39.69 and $17.06 \mu \mathrm{g} \cdot \mathrm{mL}^{-1}$, respectively, while in the aerial parts $\mathrm{Mn}$ and $\mathrm{Zn}$ metals presented the highest levels in S. verticillata with 199.18 and $85.73 \mu \mathrm{g} \cdot \mathrm{mL}^{-1}$. In the pollen, the levels of $\mathrm{Cu}, \mathrm{Mn}, \mathrm{Pb}$ and $\mathrm{Zn}$ vary from 5.44 to $11.75 \mu \mathrm{g} \cdot \mathrm{mL}^{-1} ; 34.31$ to $85.75 \mu \mathrm{g} \cdot \mathrm{mL}^{-1} ; 13.98$ to $18.19 \mu \mathrm{g} \cdot \mathrm{mL}^{-1}$ and 50.19 to $90.35 \mu \mathrm{g} . \mathrm{mL}^{-1}$, respectively. These results indicate that in the apicultural pasture the translocation (from soil to pollen) of $\mathrm{Mn}$ and $\mathrm{Zn}$ was more effective than in case of $\mathrm{Cu}$ and $\mathrm{Pb}$, therefore, the bee pollen can be used as food supplement without causing risks to human health.
\end{abstract}

Key words: bee pollen, bee plant, trace elements, translocation capacity.

\section{INTRODUCTION}

The bee pollen is a natural material of high complexity, whose composition significantly varies according to environmental variables such as: the region where it is produced, predominant flora, bees' preference, geochemical characteristics of the soil and the period of the year (Alcoforado Filho and Gonçalves 2000). From a macroscopic point of view, it is composed of botanical pollen grains that bees collect from the anthers of male or hermaphrodite flowers and moisten with

Correspondence to: Aline Santana Silva

E-mail: aline_santana@iq.unesp.br their salivary secretion, forming pellets that are transported up to the hive (Barth 1989). When it is collected at the hive's entrance and dehydrated at most $42^{\circ} \mathrm{C}$, until reaching $4 \%$ of maximum moisture level, the product is considered "dehydrated bee pollen". This is the most convenient presentation form for commercial purposes (Brasil 2001).

Despite being considered a "clean" substance, if the environment where it is produced is polluted, the pollutants can be present in its composition, sometimes in significantly high concentrations (Fredes and Montenegro 2006, Kump et al. 1996, Rashed and Soltan 2004). Two of the main pollutant sources that 
may be absorbed by the pollen are: 1) the atmospheric air, through particulate material in suspension (Ward 2000); and 2) the soil, through plants absorption and translocation (Turgut et al. 2004). In both cases the pollutants can be of organic nature as well as mineral nature. In the second case, there is a prevalence of minerals, among them heavy metals deserve special attention (Chen et al. 2004, Meers et al. 2005). This is because, in addition to the intrinsic toxicity of these metals, some bee plants also exhibit characteristics of phytoaccumulation of heavy metals, contributing to their biomagnification (Ajasa et al. 2004, Cintra et al. 2005, Ghosh and Singh 2005).

Except in cases of natural catastrophes (volcanisms, flood, etc), high levels of heavy metals in the soil are of predominately anthropic origin, as they usually occur at very low concentrations in a terrestrial environment, typically at trace and ultra-trace levels (Moura et al. 2006, Ward 2000). This means that the emergence of high levels of heavy metals in the pollen should be mainly credited to other factors and not to their expressive abundance in this place. Two factors that may be determinant in situations like that are: 1) these metals are of intrinsically cumulative character in living tissues; 2) there are some polliniferous plants that are also good accumulators of these metals (Azeredo et al. 2003, Barth 1989).

Actually, some plant species are known and well characterized regarding their capacity to accumulate high levels of heavy metals in their biomass. They are classified as hyperaccumulators (Meers et al. 2005, Pollard and Baker 1997, Visoottiviseth et al.2002, Wei et al.2006). According to specialized literature (Yoon et al. 2006) there are reports of about 400 plant species that present this phenomenon. From this estimated amount, 26 plant species are selective for cobalt, 24 are selected for copper, 8 are selected for manganese, 145 are selected for nickel, 5 are selected for lead and 4 plant species are selected for zinc.

Although the hyperaccumulation phenomenon is not a nutritional need for the plant, but only a tolerance that is superior than the average of other species, this also represents a peculiar characteristic of each species or group of species (Oven et al. 2002). Thus, in regions where apiculture is practiced for commercial purposes, the identification of bee plants with this characteristic is an important item to be evaluated, in order to assure that the product fully meets technical and sanitary specifications imposed by the regulatory agencies and the demanding consumer market of modern times.

This work aims to characterize the plants and bee pollen produced in Teresina, regarding the contents of $\mathrm{Cu}, \mathrm{Mn}, \mathrm{Pb}$ and $\mathrm{Zn}$, as well as their consequences to the quality of the product.

\section{MATERIALS AND METHODS}

\section{REAGENTS AND SOLUTION}

All reagents employed in this study were of analytical grade and they were used without previous purification. In order to prepare the solutions, it was used ultra pure water $(18 \mathrm{M} \Omega \mathrm{cm})$ obtained through the Milli-Q purification system (Millipore, RO15). The analytical curves to determine the studied heavy metals $(\mathrm{Cu}, \mathrm{Mn}, \mathrm{Pb}$ and $\mathrm{Zn}$ ) were constructed by adequate dilutions of stock solutions of the respective high purity standards, containing $1,000 \mu \mathrm{g} \cdot \mathrm{mL}^{-1}$ of each metal.

APPARATUS

For the plants samples pulverization it was used a mill (Fritsch, Pulverisette 14) that was equipped with a sieve of $0.50 \mathrm{~mm}$ mesh embedded in a stainless steel hollow.

The mineralization of the samples was carried out using a digestion system (Digestor, Quimis Model) equipped with an aluminum block of 42 tubes capacity $(0.1 \mathrm{~L})$ and a temperature controller.

In order to obtain the analytical determinations, it was used an atomic absorption spectrophotometer (Varian, SpectrAA 220 FS). A hollow cathode lamp of each metal was used as a radiation source and it 
TABLE I

Wavelength, experimental conditions and parameters of the calibration curve to the analyzed metals.

\begin{tabular}{cccccccc}
\hline Metals & $\begin{array}{c}\text { Wavelength } \\
(\mathrm{nm})\end{array}$ & $\begin{array}{c}\text { Slit width } \\
(\mathrm{nm})\end{array}$ & $\begin{array}{c}\text { Current lamp } \\
(\mathrm{mA})\end{array}$ & $\begin{array}{c}\text { Gas flow } \\
(\text { Air/Acetilene }) \\
\left(\text { L.min }^{-1}\right)\end{array}$ & $\begin{array}{c}\text { Linear range } \\
\left(\mu \mathrm{g} \cdot \mathrm{mL}^{-1}\right)\end{array}$ & Regression equations & $\begin{array}{c}\text { Correlation } \\
\text { coefficient }\end{array}$ \\
\hline $\mathrm{Cu}$ & 324.8 & 0.5 & 4.0 & $11.00 / 2.0$ & $0.1-1.3$ & $\mathrm{~A}=0.0622 \times \mathrm{C}-0.0006$ & 0.9992 \\
\hline $\mathrm{Mn}$ & 279.5 & 0.2 & 5.0 & $13.50 / 2.0$ & $0.1-2.2$ & $\mathrm{~A}=0.0575 \times \mathrm{C}-0.0048$ & 0.9966 \\
\hline $\mathrm{Pb}$ & 217.0 & 1.0 & 5.0 & $13.50 / 2.0$ & $0.1-1.3$ & $\mathrm{~A}=0.0212 \times \mathrm{C}+0.0010$ & 0.9932 \\
\hline $\mathrm{Zn}$ & 213.9 & 1.0 & 5.0 & $13.50 / 2.0$ & $0.1-1.9$ & $\mathrm{~A}=0.3306 \times \mathrm{C}+0.0076$ & 0.9999 \\
\hline
\end{tabular}

was measured under optimum operating conditions with an air-acetylene flame. The instrumental conditions and parameters were selected according to the recommendations mentioned in the equipment's instructions manual (Analytical Methods 1989), as presented in Table I.

PREPARATION OF SAMPLES AND ANALYTICAL DETERMINATION

The collecting of samples was carried out in the Apicultural Sector of the Center for Agricultural Sciences of the Universidade Federal do Piauí, settled in an area covered by native plant species (localization: $05^{\circ} 05^{\prime} 21^{\prime \prime} \mathrm{S}, 42^{\circ} 48^{\prime} 07^{\prime \prime} \mathrm{W}$, altitude: $72 \mathrm{~m}$ ).

The plant species utilized in this study were: Bauhinia platypetala, Hyptis suaveolens, Mimosa caesalpiniafolia and Spermacoce verticilata. Samples of roots and aerial parts of each plant were collected during the blossom period (March and June/2006). They were washed in current and distilled water and left to dry in a stove for 48 hours, at a temperature of $75^{\circ}$ to $80^{\circ} \mathrm{C}$. In the next step, samples were pulverized and dried again at the same temperature, until they reached a constant weight. Portions of approximately $1.0 \mathrm{~g}$ of samples were digested in an acidic mixture of nitric and perchloric acid (Ghosh and Singh 2005). The obtained solutions were diluted to the volume of about $50 \mathrm{~mL}$.

The pollen was monthly collected, from Apis mellifera hives of the same area, between January and December, 2006. After the samples have been dehydrated and homogenized, they were stored in plastic bags at a temperature of approximately $-18^{\circ} \mathrm{C}$. The samples of $1 \mathrm{~mm}$ grain size dried previously to the constant mass at $50^{\circ} \mathrm{C}$ for 12 hours were mineralized according to the already described procedure for plants and analyzed by flame atomic absorption spectrophotometry.

\section{RESULTS AND DISCUSSION}

VALIDATION

The limits of detection (LOD) and quantification (LOQ) presented in Table II were determined according to Ribani et al. (2004), by using Equations (1) and (2).

$$
\begin{aligned}
& \mathrm{LOD}=3.33 \times(\mathrm{s} / \mathrm{S}) \\
& \mathrm{LOQ}=10 \times(\mathrm{s} / \mathrm{S})
\end{aligned}
$$

where " $\mathrm{s"}$ " is the standard deviation of the measures referring to the blank $(n=20)$ and " $\mathrm{S}$ " is the inclination of the analytical curve.

The recovery test of each metal was carried out based on the improvement of the samples solutions, by adding adequate aliquots of metals standard solutions, in order to obtain final concentrations of 0.4 and $0.8 \mu \mathrm{g} \cdot \mathrm{mL}^{-1}$ in the work solutions. The results were calculated according to Equation (3).

$\% \mathrm{R}=\left(\mathrm{c}_{\mathrm{i}}-\mathrm{c}_{0} / \mathrm{C}_{\mathrm{i}}\right) \times 100$

where $c_{i}$ is the final concentration of the improved work solutions, $\mathrm{c}_{0}$ is the concentration of the work solution without improvement and $C_{i}$ is the final concentration of the standard solution. The results are presented in Table II. 
TABLE II

LOD, LOQ values and recovery test used in the analytical determination of $\mathrm{Cu}, \mathrm{Mn}, \mathrm{Pb}$ and $\mathrm{Zn}$.

\begin{tabular}{|c|c|c|c|c|c|}
\hline \multirow{2}{*}{ Metals } & \multirow{2}{*}{$\begin{array}{c}\text { LOD } \\
\left(\mu \mathrm{g} \cdot \mathrm{mg}^{-1}\right)\end{array}$} & \multirow{2}{*}{$\underset{\left(\mu \mathrm{g} \cdot \mathrm{mg}^{-1}\right)}{\mathrm{LOQ}}$} & \multicolumn{3}{|c|}{ Recovery } \\
\hline & & & $\mathrm{C}_{\mathrm{i}}\left(\mu \mathrm{g} \cdot \mathrm{mL}^{-1}\right)$ & $\mathrm{c}_{\mathrm{i}}\left(\mu \mathrm{g} \cdot \mathrm{mL}^{-1}\right)$ & $\mathrm{R}(\%)$ \\
\hline \multirow{3}{*}{$\mathrm{Cu}$} & \multirow{3}{*}{0.071} & \multirow{3}{*}{0.24} & - & $0.162(2.45 \%)^{*}$ & - \\
\hline & & & 0.40 & $0.531(1.14 \%)$ & 92 \\
\hline & & & 0.80 & $0.903(3.10 \%)$ & 93 \\
\hline \multirow{3}{*}{$\mathrm{Mn}$} & \multirow{3}{*}{0.054} & \multirow{3}{*}{0.17} & - & $1.93(0.572 \%)$ & - \\
\hline & & & 0.40 & $2.34(1.19 \%)$ & 102 \\
\hline & & & 0.80 & $2.84(0.701 \%)$ & 113 \\
\hline \multirow{3}{*}{$\mathrm{Pb}$} & \multirow{3}{*}{0.072} & \multirow{3}{*}{0.23} & - & $0.422(1.65 \%)$ & - \\
\hline & & & 0.40 & $0.784(3.72 \%)$ & 91 \\
\hline & & & 0.80 & $1.19(3.01 \%)$ & 96 \\
\hline \multirow{3}{*}{$\mathrm{Zn}$} & \multirow{3}{*}{0.031} & \multirow{3}{*}{0.095} & - & $1.64(1.70 \%)$ & - \\
\hline & & & 0.40 & $1.99(4.41 \%)$ & 87 \\
\hline & & & 0.80 & $2.40(3.45 \%)$ & 95 \\
\hline
\end{tabular}

* Average of the concentrations ( $\%$ coefficient of variation, $\mathrm{n}=3$ ).

The observed recovery results situated between $87 \%(\mathrm{~Pb})$ and $113 \%(\mathrm{Mn})$, with coefficients of variation lower than $10 \%$. These data indicate that, despite the material complexity, the interferences due to the effects of the matrix are insignificant (Ribani et al. 2004) and therefore, the employed methodology is adequate to the referred product.

\section{TrANSLOCATION OF METALS}

The collected levels of metals in the soil and in the two different bee plant species (roots and aerial parts) are shown in Table III.

The levels of metals encountered in the soil are relatively low in relation to the reference values usually accepted as risk thresholds for human health and the environment (Falco et al. 2005). Although there is no consensus about this question, some specialists, institutions and governments use the limits $(\mathrm{X} \pm 2 \mathrm{~s})$ and $100(\mathrm{X} \pm 2 \mathrm{~s})$ as criterion to characterize the existence of risk in soil that was not polluted by human activity-except for agricultural purposes-where $\mathrm{X}$ is the average and $\mathrm{s}$ is the standard deviation of the levels presented in the referred area (Gil et al. 2004). According to this criterion, only Mn (with $\mathrm{X}=18.60$ and $\mathrm{s}=0.751 \mu \mathrm{g} \cdot \mathrm{mg}^{-1}$ ) represents some approximating threat to this critical range or risk threshold for non-polluted soils. However, it has to be taken into account that these parameters should only be considered as local or regional guidelines, and they are also limited in time. The time limitation, even in protected areas, is essentially related to the dynamics of metals by aerial or aquatic ways that allow its "spontaneous" occurrence in these areas, even when the generating source is miles away (Micó et al. 2007, Reimann et al. 2001).

It is important to observe that low levels of metals in the soil do not necessarily mean low levels of metals in the plant. Different species can present not only different tolerances to high levels, but also different capacities of extracting and directing the accumulation of metals from the soil to the different parts of the vegetable (Rodella 2005). The metals capacity of translocation from the soil to the roots (CTR), from the soil to the aerial parts (CTA) and 
TABLE III

Levels of metals $\left(\mu \mathrm{g} \cdot \mathrm{mg}^{-1}\right)$ and the coefficient of variation (\%) found in the soil and in the studied plants (except $\mathrm{Cu}$ in $S$. verticiliata).

\begin{tabular}{|c|c|c|c|c|c|c|c|c|c|}
\hline \multirow[b]{2}{*}{ Metals } & \multirow{2}{*}{$\begin{array}{c}\text { Soil } \\
\left(\mu \mathrm{g} \cdot \mathrm{mL}^{-1}\right)\end{array}$} & \multicolumn{2}{|c|}{ B. platypetala } & \multicolumn{2}{|c|}{ H. suaveolens } & \multicolumn{2}{|c|}{ M caesalpiniaefolia } & \multicolumn{2}{|c|}{ S. verticillata } \\
\hline & & $\begin{array}{c}\text { Roots } \\
\left(\mu \mathrm{g} \cdot \mathrm{mL}^{-1}\right)\end{array}$ & $\begin{array}{l}\text { Aerial parts } \\
\left(\mu \mathrm{g} \cdot \mathrm{mL}^{-1}\right)\end{array}$ & $\begin{array}{c}\text { Roots } \\
\left(\mu \mathrm{g} \cdot \mathrm{mL}^{-1}\right)\end{array}$ & $\begin{array}{l}\text { Aerial parts } \\
\left(\mu \mathrm{g} \cdot \mathrm{mL}^{-1}\right)\end{array}$ & $\begin{array}{c}\text { Roots } \\
\left(\mu \mathrm{g} \cdot \mathrm{mL}^{-1}\right)\end{array}$ & $\begin{array}{l}\text { Aerial parts } \\
\left(\mu \mathrm{g} \cdot \mathrm{mL}^{-1}\right)\end{array}$ & $\begin{array}{c}\text { Roots } \\
\left(\mu \mathrm{g} \cdot \mathrm{mL}^{-1}\right)\end{array}$ & $\begin{array}{c}\text { Aerial parts } \\
\left(\mu \mathrm{g} \cdot \mathrm{mL}^{-1}\right)\end{array}$ \\
\hline $\mathrm{Cu}$ & $\begin{array}{c}1.72 \\
(2.63 \%)\end{array}$ & $\begin{array}{c}47.35 \\
(16.19 \%)\end{array}$ & $\begin{array}{c}8.09 \\
(2.95 \%)\end{array}$ & $\begin{array}{c}39.69 \\
(9.72 \%)\end{array}$ & $\begin{array}{c}9.75 \\
(12.91 \%)\end{array}$ & $\begin{array}{c}8.88 \\
(11.61 \%)\end{array}$ & $\begin{array}{c}4.87 \\
(17.10 \%)\end{array}$ & $<$ LOD & $<$ LOD \\
\hline $\mathrm{Mn}$ & $\begin{array}{c}18.60 \\
(4.06 \%)\end{array}$ & $\begin{array}{c}18.29 \\
(13.21)\end{array}$ & $\begin{array}{l}66.58 \\
(1.50)\end{array}$ & $\begin{array}{c}59.60 \\
(5.55 \%)\end{array}$ & $\begin{array}{c}89.15 \\
(4.30 \%)\end{array}$ & $\begin{array}{c}17.32 \\
(7.01 \%)\end{array}$ & $\begin{array}{c}48.18 \\
(3.49 \%)\end{array}$ & $\begin{array}{c}54.67 \\
(2.69 \%)\end{array}$ & $\begin{array}{c}199.18 \\
(2.27 \%)\end{array}$ \\
\hline $\mathrm{Pb}$ & $\begin{array}{c}0.58 \\
(5.87 \%)\end{array}$ & $\begin{array}{c}32.71 \\
(12.43)\end{array}$ & $\begin{array}{c}11.88 \\
(0.24 \%)\end{array}$ & $\begin{array}{c}17.06 \\
(3.43 \%)\end{array}$ & $\begin{array}{c}13.47 \\
(5.26 \%)\end{array}$ & $\begin{array}{c}14.74 \\
(1.84 \%)\end{array}$ & $\begin{array}{c}11.68 \\
(4.70 \%)\end{array}$ & $\begin{array}{c}17.10 \\
(12.19 \%)\end{array}$ & $\begin{array}{c}16.29 \\
(2.03 \%)\end{array}$ \\
\hline $\mathrm{Zn}$ & $\begin{array}{c}1.84 \\
(4.65 \%)\end{array}$ & $\begin{array}{c}30.97 \\
(5.65 \%)\end{array}$ & $\begin{array}{c}35.19 \\
(3.03 \%)\end{array}$ & $\begin{array}{c}26.32 \\
(5.08 \%)\end{array}$ & $\begin{array}{c}40.37 \\
(0.13 \%)\end{array}$ & $\begin{array}{c}11.99 \\
(4.86 \%)\end{array}$ & $\begin{array}{c}31.06 \\
(9.82 \%)\end{array}$ & $\begin{array}{c}19.62 \\
(1.11 \%)\end{array}$ & $\begin{array}{c}85.73 \\
(3.43 \%)\end{array}$ \\
\hline
\end{tabular}

from the roots to the aerial parts, so called intrinsic translocation (CTI), are defined in the equations (4-6), where MCR, MCA and MCS are the metals concentrations in the roots, in the aerial parts and in the soil, respectively. Sometimes these parameters determine the effects produced by the metal in the plant, e.g. the development of toxicity (Nobre et al. 2004, Robinson et al. 1999).

$$
\begin{aligned}
& \mathrm{CTR}=\mathrm{MCR} / \mathrm{MCS} \\
& \mathrm{CTA}=\mathrm{MCA} / \mathrm{MCS} \\
& \mathrm{CTI}=\mathrm{MCA} / \mathrm{MCR}
\end{aligned}
$$

Besides, according to Wei et al. (2006), these parameters are also important to distinguish the non-accumulating or moderately tolerant species, from the hyper-accumulating or highly tolerant species (Yoon et al. 2006). Generally, the enrichment factor (EF), that may assume any of the above expressions, since it has been specified, provides good information about the plant's potential to hyper-accumulation and through which process this state is achieved. Particularly, high values of CTR combined with low values of the CTI in a certain plant means an advantageous situation in case of bee plants and oleraceas, in general (except to edible tubers and rhizomes), because their development in contaminated soil normally occur, and they can accumulate high levels of metal (in roots), without compromising the useful aerial parts (leaves, flowers, fruits and seeds). In places suspected of being contaminated by heavy metals, it is recommended to cultivate plants with this characteristic, because it enables the production of food in a potentially useless or dangerous type of soil. At the same time, this type of plants can be used as phytorremediators of the cultivated area, by removing it and burning it, in order to obtain the metal's bio-ore (Reimann et al. 2001, Anderson et al. 1999).

In regions without an intense industrial activity (as in the focused case), it is prudent to admit that the absorption of metals in the air by leaves and flowers is negligible. Otherwise, it will be necessary to monitor the air of the region in order to identify the metal's intake route in the plant (soil or air) and then decide whether the cultivation of species with high CTR and low CTI is viable or not.

The found values of the metals capacity of translocation, from the soil to the roots (CTR), from the soil to the aerial parts (CTA) and from the roots to the aerial parts (CTI) in B. platypetala, $H$. suaveolens, M. caesalpiniaefolia and $S$. verticillata species are demonstrated in Table IV.

Based on Table IV data, it is possible to critically evaluate the real significance of high and low levels of metals in the soil, considering the tested plant species. It is observed that $\mathrm{Pb}$ and $\mathrm{Zn}$, despite being presented at low levels in the soil ( 0.58 and $\left.1.84 \mu \mathrm{g} \cdot \mathrm{mg}^{-1}\right)$, exhibit the highest values 
TABLE IV

Values of CTR, CTA and CTI for the analyzed metals.

\begin{tabular}{cccccc}
\hline \multirow{2}{*}{ Species } & Translocation & \multicolumn{3}{c}{ Metals } \\
\cline { 3 - 6 } & & $\mathrm{Cu}$ & $\mathrm{Mn}$ & $\mathrm{Pb}$ & $\mathrm{Zn}$ \\
\hline \multirow{3}{*}{ B. platypetala } & CTR & 27.53 & 0.98 & 56.40 & 16.83 \\
& CTA & 4.70 & 3.58 & 20.48 & 19.12 \\
\multirow{3}{*}{ H. suaveolens } & CTI & 0.17 & 3.64 & 0.36 & 1.14 \\
& CTR & 23.07 & 3.20 & 29.41 & 14.30 \\
M. caesalpiniaefolia & CTA & 5.67 & 4.80 & 23.22 & 21.94 \\
& CTI & 0.24 & 1.50 & 0.79 & 1.53 \\
& CTR & 5.16 & 0.93 & 25.41 & 6.52 \\
S. verticillata & CTA & 2.83 & 2.59 & 20.14 & 16.88 \\
& CTI & 0.55 & 2.78 & 0.79 & 2.59 \\
& CTR & - & 2.94 & 29.48 & 10.66 \\
& CTA & - & 10.71 & 28.09 & 46.59 \\
& CTI & - & 3.64 & 0.95 & 4.37 \\
\hline
\end{tabular}

of CTR and CTA in both species, while Mn, that has the highest level in the soil $\left(18.60 \mu \mathrm{g} \cdot \mathrm{mg}^{-1}\right)$, exhibits very low values of CTR and CTA in comparison to $\mathrm{Pb}$ and $\mathrm{Zn}$. Besides, all the values of CTI are very low, indicating that, even in cases where there is a significant accumulation of metals in the plants, this occurs preferentially in the roots and, therefore, these two species have an insignificant importance as tributaries of those metals in the bee pollen produced in this region.

SeAsonal VARiations of $\mathrm{Cu}, \mathrm{Mn}, \mathrm{Pb}$ AND Zn LeVELS IN THE BEe POLlEN FROM TERESINA REgION

The average levels of $\mathrm{Cu}, \mathrm{Mn}, \mathrm{Pb}$ and $\mathrm{Zn}$ that were found in the analyzed samples of bee pollen and their respective coefficients of variation are shown in Table V.

The levels of $\mathrm{Cu}, \mathrm{Mn}, \mathrm{Pb}$ and $\mathrm{Zn}$ indicated in Table $\mathrm{V}$ are very informative regarding the seasonal dynamics of occurrence of these metals in the bee pollen from the studied region. Mn and $\mathrm{Zn}$ metals are presented in higher levels while $\mathrm{Cu}$ and $\mathrm{Pb}$ are presented in lower levels. The causes of this separation may be related to the accumulating mechanism of $\mathrm{Mn}$ and $\mathrm{Zn}$ that, according to Singh and Sinha (2005), Singh and Agrawal (2007) and Ali et al. (2006), involves complexation of the metal with groups $\left(-\mathrm{NH}_{2}\right)$ and $(-\mathrm{SH})$ of amino acid and non-peptide thiol presented in tissue plants.

$\mathrm{Cu}, \mathrm{Mn}$ and $\mathrm{Zn}$, respecting the tolerable limits, are essential micronutrients for animals and plants, and they take part in important vital processes for both types of living beings (Franco 2002). Because it does not have a known (beneficial) biological function, $\mathrm{Pb}$ is only considered a highly toxic traceelement that cause many disturbances to plants and animals health, including man and the environment (Chen et al. 2004).

Under well defined experimental conditions, Krajncic and Nemec (2003) have demonstrated that $\mathrm{Cu}, \mathrm{Mn}$ and $\mathrm{Zn}$ together participate in catalytic processes of some superior plant species, whose results are not only a sensible increase in the production of flowers, attributed to $\mathrm{Mn}$, but also an increase in the photosynthesis rate and sucrose synthesis, both due to the joint participation of $\mathrm{Cu}$ and $\mathrm{Zn}$. This somewhat would justify the fact that $\mathrm{Mn}$ and $\mathrm{Zn}$ have very similar levels in most of the samples (approximately 75\%). From that point, there is a gradient of concentration determined by the plant's nutritional needs. 
TABLE V

Average values of the metals levels ( $\mu \mathrm{g} . \mathrm{mg}^{-1}$ ) and the coefficients of variation (\%) detected in samples of the analyzed bee pollen.

\begin{tabular}{lcccc}
\hline Month & $\mathrm{Cu}$ & $\mathrm{Mn}$ & $\mathrm{Pb}$ & $\mathrm{Zn}$ \\
\hline January & $8.91(5.88 \%)$ & $34.31(3.90 \%)$ & $14.80(3.94 \%)$ & $72.48(2.95 \%)$ \\
February & $6.38(2.02 \%)$ & $43.43(7.30 \%)$ & $13.98(3.92 \%)$ & $68.96(5.95 \%)$ \\
March & $6.98(2.51 \%)$ & $85.75(5.73 \%)$ & $17.11(7.07 \%)$ & $81.77(1.66 \%)$ \\
April & $7.03(6.06 \%)$ & $82.11(9.04 \%)$ & $18.19(1.83 \%)$ & $90.35(4.50 \%)$ \\
May & $5.50(4.78 \%)$ & $43.16(4.31 \%)$ & $17.69(2.20 \%)$ & $76.49(1.89 \%)$ \\
June & $6.02(10.36 \%)$ & $58.91(2.61 \%)$ & $16.23(3.55 \%)$ & $71.42(0.73 \%)$ \\
July & $6.74(3.61 \%)$ & $41.92(2.39 \%)$ & $15.09(3.04 \%)$ & $50.84(0.26 \%)$ \\
August & $5.44(5.78 \%)$ & $56.49(2.09 \%)$ & $15.06(1.22 \%)$ & $52.28(4.17 \%)$ \\
September & $7.72(2.78 \%)$ & $59.08(6.03 \%)$ & $15.64(1.63 \%)$ & $58.41(1.62 \%)$ \\
October & $7.23(1.87 \%)$ & $53.81(3.50 \%)$ & $15.64(1.04 \%)$ & $58.52(0.93 \%)$ \\
November & $8.53(5.85 \%)$ & $42.45(3.76 \%)$ & $15.75(1.56 \%)$ & $63.67(0.60 \%)$ \\
December & $7.14(10.27 \%)$ & $47.90(3.50 \%)$ & $15.02(2.34 \%)$ & $52.16(4.58 \%)$ \\
Annual Average & $6.73(19.35 \%)$ & $54.11(29.42 \%)$ & $15.85(7.88 \%)$ & $66.44(19.02 \%)$ \\
\hline
\end{tabular}

In these results, $\mathrm{Cu}$ is the element that presented lower levels; this characteristic may be related to the necessary levels to carry out specific catalytic functions, once the required concentration of $\mathrm{Cu}$ is approximately 7 times smaller than the $\mathrm{Zn}$ concentration and, about 12 times smaller than the Mn one (Krajncic and Nemec 2003). The modest $\mathrm{Cu}$ diet (while useful), the inevitable physiological disorders originated from an accidental luxurious diet (Epstein 1975) and the zero lack regarding $\mathrm{Pb}$ may induce some plant's defense mechanism, like retention in the roots (Xu et al. 2007). For that matter, in case of $\mathrm{Cu}$, an initial imprisonment of the metal in the form of metallothionein is suggested, followed by a precipitation as phosphate that is deposited in the cellular vacuoles (Rau et al. 2007). As for $\mathrm{Pb}$, especially in the status of oxidation (2+)the most available form in the soil and the greatest affinity for thiolic groups-, it is reasonable to credit their known toxicity to the competition with other divalent metals, especially Zn, substituting it in their respective metallothioneins (Magyar et al. 2005):

$$
\underset{\text { (flat square) }}{\mathrm{Zn}(\text {-thionein })_{4}}+\mathrm{Pb}^{2+} \rightarrow \underset{\text { (triangular pyramid) }}{\mathrm{Pb}(- \text { thionein })_{3}}+\mathrm{Zn}^{2+}
$$

The molecular interactions of $\mathrm{Pb}$-thionein complex may show a triangular pyramid geometric form, with coordination number 3 , or other geometric form when also assuming coordination numbers 5, 6 or 8 . In this case, the protein (thionein) that can be an apoenzyme totally loses its activity depending on the structural change. According to this interpretation, it is by this substitution that the high toxicity of $\mathrm{Pb}$ is manifested (Magyar et al. 2005).

\section{CONCLUSION}

The herewith presented data suggests that the already foreseen mutualism between plant and insect, whereby both benefit, is capable to induce mechanisms in the plant that turn it more attractive to insects that practice the pollination, contributing to the success of preservation and proliferation of plants' genetic materials.

The results reveal not only the important role of the plants in the selection and translocation of metals from the soil to the organ of "interest" for the plant and/or for the pollinator insects, but also that, regarding the $\mathrm{Cu}, \mathrm{Mn}, \mathrm{Pb}$ and $\mathrm{Zn}$ levels, the product is suitable for human consumption. 


\section{ACKOWLEDGMENTS}

The authors would like to thank the Fundação de Amparo à Pesquisa do Estado do Piauí (FAPEPI)/ Coordenção de Aperfeiçoamento de Pessoal de Nível Superior (CAPES) for financial support, the Graziela Barroso Herbarium/UFPI for identifying the tested species, and the Laboratório de Análise de Combustíveis (LAPETRO) for their technique support during the research.

\section{RESUMO}

O objetivo deste estudo é caracterizar plantas apícolas nativas, quanto a sua capacidade de extrair e acumular elementos-traço do solo e suas conseqüências na sanidade do pólen produzido. Os elementos-traço $\mathrm{Cu}, \mathrm{Mn}, \mathrm{Pb}$ e $\mathrm{Zn}$ foram analisados em solo, planta e pólen apícolas em Teresina (PI), Brasil, por espectrofotometria de absorção atômica com atomização em chama. Considerando as espécies de plantas estudadas, os metais $\mathrm{Cu}$ e $\mathrm{Pb}$ apresentaram nas raízes maiores teores de $B$. platypetala com 47,35 e 32,71 $\mu$ g.mL $\mathrm{mL}^{-1}$ e H. suaveolens com 39,69 e $17,06 \mu \mathrm{g} \cdot \mathrm{mL}^{-1}$, respectivamente, enquanto na parte aérea os metais $\mathrm{Mn}$ e $\mathrm{Zn}$ apresentaram os maiores teores, em S. verticillata com 199,18 e $85,73 \mu \mathrm{g} \cdot \mathrm{mL}^{-1}$. No pólen os teores de $\mathrm{Cu}, \mathrm{Mn}, \mathrm{Pb}$ e $\mathrm{Zn}$ varia de 5,44 a 11,75 $\mu \mathrm{g} \cdot \mathrm{mL}^{-1}$; 34,31 a $85,75 \mu \mathrm{g} \cdot \mathrm{mL}^{-1} ; 13,98$ a $18,19 \mu \mathrm{g} \cdot \mathrm{mL}^{-1}$ e 50,19 a 90,35 $\mu \mathrm{g} \cdot \mathrm{mL}^{-1}$, respectivamente. Esses resultados indicam que, no pasto apícola, a translocação (do solo ao pólen apícola) de $\mathrm{Mn}$ e $\mathrm{Zn}$ foi mais eficiente do que $\mathrm{Cu}$ e $\mathrm{Pb}$, portanto, o pólen apícola poderá ser utilizado como complemento alimentar sem causar riscos à saúde humana.

Palavras-chave: pólen apícola, plantas apícolas, elementos-traço, capacidade de translocação.

\section{REFERENCES}

Ajasa AMO, Bello MO, Ibrahim AO, OgunWANDE IA AND OlaWORE AO. 2004. Heavy trace metals and macronutrients status in herbal plants of Nigéria. Food Chem 85: 67-71.

Alcoforado Filho FG AND Gonçalves JC. 2000. Flora apícola e mel orgânico. Cadeia produtiva do mel no Estado do Piauí. Teresina, Embrapa Meio Norte, p. 9-12.
Ali MB, Singh N, Shohael AM, Hahn EJ And PeAK K-Y. 2006. Phenolics metabolism and lignin synthesis in root suspension cultures of Panax ginseng in response to copper stress. Plant Sci 171: 147-154.

ANAlytical Methods. 1989. Flame Atomic Absortion Spectrometry, Manual da Varian.

ANDERSON CWN, BRoOKS RR, CHIARUCCI A, LACOSTE CJ, LEBLANC M, ROBINSON BH, SIMCOCK R AND STEWART RB. 1999. Phytomining for nickel, thallium and gold. J Geochem Explor 67: 407-415.

Azeredo LC, AZEREdo MAA, SouzA SR DE AND DUTRA VML. 2003. Protein contents and physicochemical properties in honey samples of Apis mellifera of different floral origins. Food Chem 80: 249-254.

BARTH OM. 1989. O pólen no mel do Brasil. Rio de Janeiro, RJ, Gráfica Luxor, 10 p.

Brasil, Ministério da Agricultura e ABAstecimento. 2001. Portaria $\mathrm{n}^{\mathrm{o}} 574$ de 8 de dezembro de 1998 Regulamentos técnicos para a fixação de identidade e qualidade de apitoxina, de cera de abelha, de geléia real, de geléia liofilizada, de pólen apícola, de extrato de própolis.

CHEN Y, Li X AND SHEN Z. 2004. Leaching and uptake of heavy metals by ten different species of plants during an EDTA-assisted phytoextration process. Chemosphere 57: 187-196.

Cintra P, Malaspina O And Bueno OC. 2005. Plantas tóxicas para as abelhas. Arq Inst Biol 72: 547-551.

EPSTEIN EI. 1975. Nutrição mineral das plantas: princípios e perspectives. Rio de Janeiro, LTC, 254 p.

FALCO G, Llobet JM, ZAREBA S, KRZYSIAK K AND DOMINGO JL. 2005. Risck assessment of the trace elements intake through natural remedies in Poland. Trace Elem. Electroly 22: 222-226.

FRANCO G. 2002. Tabela de composição química dos alimentos. $9^{\text {a }}$ ed., São Paulo, Ateneu, p. 229-269.

FREDES C AND Montenegro G. 2006. Heavy metals and other trace elements contents in Chilean honey. Cien Inv Agr 33: $50-58$

GHOSH M AND SINGH SP. 2005. A comparative study of cadmium phytoextraction by accumulator and weed species. Environ Pollut 133: 365-371.

Gil C, Boluda R AND Ramos J. 2004. Determination and evaluation of cadmium, lead and nickel in greenhouse soils of Almería (Spain). Chemosphere 55: 1027-1034.

KRAJNCIC B AND NeMEC J. 2003. Mechanisms of EDDHA effects on the promotion of floral induction in the longday plant Lemna minor (L.). J Plant Physiol 160: 143-151.

KumP P, NECEMER M AND SNAJDER J. 1996. Determination of trace elements in bee honey, pollen and tissue by total reflection and radioisotope $\mathrm{X}$-ray fluorescence spectrometry. Spectrochim Acta 51: 499-507.

Magyar JS, Weng T-C, Stern CM, Dye DF, Rous BW, Payne JC, Bridgewater BM, Mijovilovich A, Parkin G, ZALESKi JM, PenNer-Hahn JE AND GOdwin HA. 2005. Reexamination of lead (II) coordination preferences in sulfur-rich sites: Implications for a critical mechanism of lead poisoning. J Am Chem Soc 127: 9495-9505. 
Meers E, Ruttens A, Hopgood MJ, SAmson D AND TACK FMG. 2005. Comparison of EDTA and EDDS as potential soil amendments for enhaced phytoextration of heavy metals. Chemosphere 58: 1011-1022.

Micó C, Peris M, ReCATALÁ L AND SÁNChEZ J. 2007. Baseline values for heavy metals in agricultural soil in an European Mediterranean region. Sci Total Environ 378: 13-17.

Moura MCS De, Lopes ANC, Moita GC And Moita Neto JM. 2006. Quim Nova 29: 429-435.

Nobre VMT, RIET-CORREA F, BARBosa FILHO JM, DANTAS AFM, TABOSA IM AND VASCONCELOS JS. 2004. Intoxicação por Crotalaria retusa (Fabaceae) em Eqüídeos no semi-árido da Paraíba. Pesq Vet Bras 24: 132-143.

OVEn M, GRILl E, GOLAN-GOLDHIRCH A, KUTCHAN TM AND ZENK MH. 2002. Increase of free cysteina and citric acid in plant cells exposed to cobalt ions. Phytochemistry 60: 467-474

POLLARD AJ AND BAKER AJM. 1997. Deterrence of herbivory by zinc hyperaccumulation in Thlaspi caerulescens (Brassicaceae). New Phytol 135: 655-658.

RASHED MN AND SOLTAN ME. 2004. Major and trace elements in different types of Egyptian mono-floral and non-floral bee honeys. J Food Com Anal 17: 725-735.

Rau S, Miersch J, Neumann D, Weber E and Krauss G-J. 2007. Biochemical responses of the aquatic moss Fontinalis antipyretica to $\mathrm{Cd}, \mathrm{Cu}, \mathrm{Pb}$ and $\mathrm{Zn}$ determined by chlorophyll fluorescence and protein levels. Environ Exp Bot 59: 299-306.

Reimann C, Koller F, Kashulina G, NisKaVAara H AND ENGLMAIER P. 2001. Influence of extreme pollution on the inorganic chemical composition of some plants. Environ Pollut 115: 239-252.

Ribani M, BotToli CBG, COLlins CH, JARDIM ICSF AND MELO LFC. 2004. Validação em métodos cromatográficos e eletroforéticos. Quim Nova 5: 771-780.
RoBinson BH, BROOKS RR, GREGG PEH AND KIRKMAN JH. 1999. The nickel phytoextration potential of some ultramafic soils as determined by sequential extraction. Geoderma 87: 293-304.

RoDELLA AA. 2005. Legislação sobre teores de contaminantes em fertilizantes - estudos de um caso. Rev Bras Ciênc solo 29: 797-801.

Singh RP AND AGRAWAL M. 2007. Effects of sewage sludge amendment on heavy metal accumulation and consequent responses of Beta vulgaris plants. Chemosphere 67: 22292240.

SingH S AND SinHa S. 2005. Accumulation of metals and its effects in Brassica juncea (L.) Czern. (cv. Rohini) grown on various amendments of tannery waste. Ecotoxicol Environ Saf 62: 118-127.

Turgut C, Pepe MK And Cutright TJ. 2004. The effect of EDTA and citric acid on phytoremediation of $\mathrm{Cd}, \mathrm{Cr}$ and Ni from soil using Helianthus annuus. Environ Pollut 131: 147-154.

VisootTIVISETH P, FRANCESCONI K AND SRIDOKCHAN W. 2002. The potential of Thai indigenous plant species for the phytoremediation of arsenic contaminated land. Environ Pollut 118: 453-461.

WARD NI. 2000. Trace elements. Environmental analytical chemistry, $2^{\text {nd }}$ ed., Australia, Blackwell Science, p. 360-392.

Wei S, Zhou Q AND Koval PV. 2006. Flowering stage characteristics of cadmium hyperaccumulator Solanum nigrum L. and their significance to phytoremediation. Sci Total Environ 369: 441-446.

Xu Y, YAmaJi N, Shen R AND MA JF. 2007. Sorghum roots are inefficient in uptake of EDTA-chelated lead. Ann Bot 99: 869-875.

YoOn J, CAO X, ZHOU Q AND MA LQ. 2006. Accumulation of $\mathrm{Pb}, \mathrm{Cu}$ and $\mathrm{Zn}$ in native plants growing on a contaminated Florida site. Sci Total Environ 368: 456-464. 